Yüzüncü Y1l Üniversitesi
Tarim Bilimleri Dergisi

Araştırma Makalesi (Research Article)

\title{
Ticari Yumurta Tavuğu Rasyonlarında Saptanan Renk Pigmentlerinin Yumurta Sarısı Pigment Düzeyi Üzerine Etkisi**
}

\author{
Enes ALATAŞ ${ }^{1}$, Ömer Faruk KURBAL ${ }^{2}$, Filiz KARADAŞ ${ }^{* 3}$ \\ 1,2,3Van Yüzüncü Y1l Üniversitesi, Ziraat Fakültesi, Zootekni Bölümü,65090 Van, Türkiye \\ ${ }^{1} \mathrm{https}$ //orcid.org/0000-0003-0753-0138 ${ }^{2} \mathrm{https} / / /$ orcid.org/0000-0001-5915-3042 ${ }^{3} \mathrm{https}: / /$ orcid.org/0000-0002-8187-349X \\ *Sorumlu yazar e-posta fkaradas@yyu.edu.tr
}

\section{Makale Bilgileri}

Geliş: 12.10 .2021

Kabul: 12.12 .2021

Online Yayınlanma: 15.12.2021

DOI: $10.29133 /$ yyutbd.1006046

\section{Anahtar Kelimeler}

Pigment,

Toplam ve bireysel karoten,

Vitamin,

Yumurta sarıs1.
Öz: Bu çalışmada, Muş ve Van illerinde ticari yumurta işletmelerinde yetiştirilen 32 haftalık Novagen, 44 haftalık Tinted, 45 ve 58 haftalık Lohman 1rk yumurtacı tavuklardan yumurta örnekleri ile yem örnekleri 1'er ay ara ile 3 ay süre ile alınmıştır. Yem ve yumurta sarısı öneklerinde; toplam karoten, lutein, zeaksantin kantaksantin, apoester, betakaroten gibi bireysel karoten ile vitamin A (retinol) ve vitamin E içeriği HPLC ile tespit edilmiştir. Bu çalışmada yumurta sarısı roche pigment skoru ile Minolta $\mathrm{L}^{*}$, $\mathrm{a}^{*}$ ve $\mathrm{b}^{*}$ değerleri ırk ve dönemler bazında belirlenmiştir. Yumurta sarısı roche pigment skala sonuçları 2. dönemde Tinted ırk1 tavuklar hariç genelinde Lohman ırkı tavuklarda; 1., 2., 3. dönemde Novagen ve Tinted ırkı yumurtalarından önemli ölçüde yüksek saptanmıştır. Minolta a* değerleri Lohman ırkı tavuklarda yumurta sarısının Novagen ırkı tavuklarının yumurta sarılarına göre daha koyu kırmızı olduğunu göstermiştir. Minolta $b^{*}$ değerleri bakımından 2. dönemde irklar arasında istatistiksel farklılık tespit edilmezken; 1. dönemde Novagen ve Tinted irkı tavuklarda yumurta sarılarının Lohman ırkı tavukların yumurta sarılarından önemli düzeyde daha sarı oldukları gözlenmiştir. Yumurta sarısı toplam karoten içerikleri 1. dönemde en düşük Tinted 1rkı yumurtalarında saptanırken, 2. dönem bir farklılık saptanmamış olup, 3. dönemde en düşük total karoten içeriği Novagen 1 rkı tavuk yumurtalarında saptanmıştır. Bu çalışma sonuçları marketteki her bir yumurtanın pigment ve vitamin içeriklerinin tüketilen yemlerin bir yansıması olarak değişik olabileceği sonucuna varılmıştır.

\section{The Effect of Color Pigments Detected in Commercial Layer Diet on Egg Yolk Pigment Level}

\section{Article Info}

Received: 12.10 .2021

Accepted: 12.12 .2021

Online Published: 15.12.2021

DOI: $10.29133 /$ yyutbd. 1006046

\section{Keywords}

Pigment,

Total and Individual

Carotene,

Vitamin,
Abstract: In this study, egg samples and feed samples were taken from 32-weekold Novagen, 44-week-old Tinted, 45 and 58-week-old Lohman laying hens reared in commercial egg farms in Muş and Van provinces for three months with 1-month intervals. Total carotene, lutein, zeaxanthin canthaxanthin, apoester and betacarotene as an individual carotene, vitamin A (retinol) and vitamin E content of egg yolk and feed samples were determined by HPLC. In this study, the roche scale and Minolta $\mathrm{L}^{*}, \mathrm{a} *$ and $\mathrm{b} *$ values of egg yolk were determined on the base of breed and periods. Egg yolk roche pigment scale results showed that except Tinted breed chickens in the second period, in general Lohman breed chickens were significantly higher in the 1st, 2nd, 3rd periods than Novagen and Tinted breeds egg yolk. Minolta a* values showed that generally egg yolks of Lohman chickens were 
Egg Yolk.

darker red than Novagen egg yolks. While, minolta $b^{*}$ values were not statistically different among breeders in the second period, it has been observed that Novagen and Tinted breed hens egg yolks were significantly yellower than Lohman hen egg yolk in the first period, but the opposite was observed in the third period. While egg yolk total carotene contents were found to be lowest in Tinted breed eggs in the first period, no difference was found in the second period and the lowest total carotene content was found in Novagen breed chicken eggs in the third period. The results of this study concluded that the pigment and vitamin content of each egg in the market may vary as a reflection of consumed feeds.

**Bu çalışma, Enes ALATAŞ’ın “Ticari yumurta tavuğu rasyonlarında saptanan renk pigmentlerinin yumurta sarısı pigment düzeyi üzerine etkisi” isimli yüksek lisans tezinden üretilmiştir.

\section{Giriş}

Yumurta tavukçuluğu ülkemiz hayvancılığı içinde oldukça önemli bir yere sahiptir (Kaya ve Macit, 2019). Yumurta, Türkiye ve dünyada insanların kaliteli protein ihtiyaçlarının karşılanmasında kullanılan hayvansal kökenli önemli bir besindir. Tüketicinin tercihleri doğrultusunda tüketiciye kaliteli yumurta sunulmalıdır. Yumurta sarısının rengi yumurta kalite parametrelerinden birisidir. Yumurta sarısının rengi tüketiciler için önemli bir kriterdir ve tüketicilerin satın alma davranıșlarını etkilemektedir. Birçok Avrupa Ülkesinde (Almanya, İngiltere, İtalya, Fransa, Polonya) tüketiciler ile yapılan anket çalışmalarında tüketicilerin daha koyu yumurta sarısına sahip serbest dolaşan tavuk yumurtalarını market yumurtalarına tercih ettikleri ve bu yumurtaların market yumurtalarına göre daha besleyici ve daha doğal olduğuna inandıklarına dair bildirişler mevcuttur (Nys, 2000). Yumurta sarısında ve etlik piliç derisinde istenen sarı rengi elde etmek amacıyla Avrupa Birliği'nde (EU) 1970'li yıllardan beri yem katkı maddesi olarak kanatlı rasyonlarında karotenler ve ksantofiller kullanılmaktadır (Surai, 2002; Alay ve Karadas, 2016).

Yumurtaya sarı renk pigmentini veren karotenler doğal renk maddesi grubunda yer alıp, doğada 750'den fazla bileşikten oluşmaktadırlar (Surai, 2002; Kushwaha ve ark., 2014). Karotenler bioaktif maddeler olup esas olarak bitki, mantar, bakteri ve algler tarafından sentezlenirler (Kushwaha ve ark.,, 2014). Ayrıca karotenler yağda çözünen moleküller olup, oksijen, sıcaklık ve 1şığa duyarlılığ1 olan kimyasal bileşiklerdir (Ciapara ve ark., 2004). Evcil hayvanlar tarafından sentezlenemeyen karotenlerin hayvan yemlerine ilave edilerek verilmesi gerekmektedir. Hayvan bünyesinde yumurtaya ve etlik piliçlerde deriye renk vermesinin yansıra; diğer biyolojik özellikleri, hayvanlarda retinoik asidin sentezlenmesinde görev alarak görme pigmenti olarak rol almaktadırlar (Vershinin, 1999). Karotenlerin bağışıklık sistemini güçlendirme, antioksidan aktivite gösterme, katarakt gibi yaşlanmaya bağlı dejenaratif hastalıkları azaltma, antiobesite/hipolipidik özellikleri ile endokrin sisteminde görev aldıkları da ileri sürülmektedir (Kushwaha ve ark., 2014).

Karotenoidler yalnızca algler, bakteriler, funguslar ve bitkiler tarafindan sentezlendiklerinden (Gürbüz ve ark., 2004), tüketicilerin tercih ettiği koyu yumurta sarısının sağlanabilmesi için yemlerdeki pigment maddelerinin sentetik ve doğal kaynaklı formları 1970'li yıllarından beri yem katkı maddesi olarak uygulanmaktadır. Yumurta sarısının rengi yemlerde bulunan karoten miktarına ve bu karotenlerin yumurtaya geçip depolanabilme özelliğine bağlıdır. Yem ile tüketilen miktara bağlı olarak yumurta sarısındaki karoten miktarı değişmekle birlikte tavuklar yemlerdeki renk maddelerinin ancak \% 14'ünü yumurta sarısında biriktirebilmektedirler. Renk maddelerinin yumurta sarısında birikmeleri, yem tüketimi ile başlamakta ve 9-12 gün içerisinde doygunluk noktasına ulaşmaktadır (Kırkpınar ve Erkek, 1999; Karadaş ve ark., 2006). Ancak, son yıllarda sentetik kökenli renk maddelerinin karsinojen, teratojenik ve toksik etkilerinden ötürü hayvan yemlerinde kullanılmaları azalma eğilimi gösterdiği (Kushwaha ve ark., 2014) ve mikrobiyal kökenli güvenli doğal pigment kaynaklarına bir yönelme olduğu görülmektedir (Dufossé ve ark., 2005; Kumar ve ark., 2015).

Doğal renk maddeleri çoğunlukla kadife çiçeği, alg, mısır, mısır gluten unu ve yonca gibi doğal yem maddeleri ile sağlanmaktadır (NRC, 1994; Leeson ve Summers, 1997). Misırda yoğun olarak bulunan zeaksantin, lutein ve betakaroten, kuru yeşil yemlerde yaygin olarak bulunan lutein ve betakaroten, kırmızı biberde yaygın olarak bulunan ve kırmızı pigment olarak kullanılan kapsaksantin, marigol çiçeğinde lutein, ve domateste bulunan likopen gibi karotenler doğal karoten kaynakları olarak 
kullanılmaktadırlar. Sentetik renk maddeleri ise dünyada ve ülkemizde yaygın olarak kantaksantin (kırmız1 pigment) ve apoester (sarı pigment) pigmentleri kullanılmaktadır (Jeroch ve ark., 1993). Yumurta tavuğu yemlerinde kullanılan karotenoidler, ksantofiller ve oksikarotenoidler yumurta sarısının koyulaşmasını sağlarlar (Latscha, 1990). Sarı renk lutein-sarısı, zeaksantin-altın sarısı ve kırmızı renk kantaksantin, astaksantin ve kapsorubin gibi maddelerden sağlanmaktadır. Kırmızı ve sarı rengi sağlayan renk maddelerinin yemde istenilen oranda bulunması büyük önem taşımaktadır (Jeroch ve ark., 1999).

Köy tipi işletmelerde tavuklar gezerek gereksinim duydukları renk maddelerini yeşil otlar, böcekler ve gübrelerden elde ederler. Ancak günümüzde artık köy tipi işletmeler, yerini kapalı sistemlere bıraktığından gereksinim duyulan tüm renk maddeleri yemlere katılmaktadır (Kırkpınar ve Erkek, 1999). Ancak, yumurta tavukları ksantofilleri sentezleyemediklerinden, istenilen renk üniformitesi yemdeki karotenoidlerin renklendirme kapasitesine ve stabilitesine bağlidır (Gürbüz ve ark., 2004).

Dünyada ve ülkemizde yumurta tavuğu ve bıldırcın rasyonlarında, pigment içermeyen buğday esaslı yemlere renk pigmenti ilavesinin yumurta sarısının pigment skoru, karoten içeriği ve yumurta verimi üzerine etkisini belirlemek için Jeroch ve ark. (1999), Kırkpınar ve Erkek (1999), Knoblich ve ark. (2000), Gürbüz ve ark. (2004), Şamlı ve ark. (2005), Günal ve Bakırcı (2006), Karadaş ve ark. (2006), Karageçili ve Karadaş (2015), Alay ve Karadas (2016) tarafından bir çok deneysel çalışma yapılmasına rağmen, ticari yumurta tavuğu yetiştiriciliği yapılan işletmelerde üretilen ve insan tüketimi için markette satışa sunulan yumurtaların karoten kompozisyonu ile ilgili çalışma yok denecek kadar azdir.

Karageçili ve Karadaş (2015) tarafından yapılan bir çalışmada; 33., 43. ve 53. haftalarda Lohmann ve 48., 58. ve 68. haftalarda Hy-Line yumurta tavuğu yemlerinin toplam karoten, vitamin A, vitamin $\mathrm{E}$ düzeylerinin hayvan yaşına göre yumurta sarısında birikimlerinin nasıl etkilendiğini araştırmışlardır. Çalışma sonunda; yumurta sarısındaki Lohmann ırkı için sırasıyla toplam karoten içeriği 19.93, 16.85 ve $18.14(\mu \mathrm{g} / \mathrm{g})(\mathrm{p}>0.05)$; Hy-Line 1rkında bu değerler sirasiyla 16.72, 17.00 ve $18.32(\mu \mathrm{g} / \mathrm{g})(\mathrm{P}<0.05)$ olarak saptanmıştır. Ayrıca Lohmann ırkı yumurta sarısı toplam vitamin A içeriği sırasıyla 3.86, 4.34 ve $3.44(\mu \mathrm{g} / \mathrm{g})$ iken Hy-Line 1 rk1 için sırasıla 7.64, 3.55 ve $3.45(\mu \mathrm{g} / \mathrm{g})$ olarak bildirilmiş̧ir $(\mathrm{P}<0.05)$. Yumurta sarısı toplam vitamin E içeriği Lohmann ırkı için sırasıyla 110.55, 111.03 ve $115.85(\mu \mathrm{g} / \mathrm{g})$ ve Hy-Line 1 rkı için sirasıyla 99.31, 97.89 ve $110.01(\mu \mathrm{g} / \mathrm{g})$ olarak saptanmışırı $(\mathrm{P}>0.05)$. Araştırma sonucunda yumurtacı tavukların yaşları arttıkça yumurta büyüklügü de artmakta ve birim hacimde biriken vitamin miktarı azalabileceği ancak yemler bu azalışı telafi edecek şekilde yeniden formülize edildiği takdirde bu olumsuzluk giderilebileceği vurgulanmıştır.

$\mathrm{Bu}$ çalışmada farklı ticari işletmelerde yetiştirilen farklı 1rk ve yaşlardaki yumurta tavuklarının yemlerinde ve yumurtalarından örnekler alınarak, yumurta karoten ve vitamin içerikleri ile yumurtanın Roche skala renk skorları (RCF), yumurtanın Minolta renk ölçüm sonuçları incelenmiş ve firmadan firmaya incelenen kriterler bakımından farklılık olup olmadığ ortaya konmuştur.

\section{Materyal ve Yöntem}

\subsection{Yem ve Yumurta Materyali}

Denemede kullanılan yem ve yumurta materyalleri Muş ilinde 2, Van ilinde 1 ticari yumurta üreticisi firmadan 1'er ay ara ile 3 kez alınmıştır.

Muş 1. Firma: Novagen White irk1 tavuklardan 32; 37 ve 41 . haftalarda 4 -5 hafta yaklaşık 1'er ay ara ile 3 ay süresince her defasinda sürüyü temsilen rastgele 10'ar adet toplamda 30 adet yumurta örneği alınmıştır. Her dönem bu tavukların beslendiği yemlerden de eş zamanlı yem örnekleri alınmıştır.

Muş 2. Firma: Tinted irk1 tavuklardan 44, 48 ve 52 haftalı yaşta 10 'ar adet toplam 30 adet yumurta örneği alınmıştır. Aynı şekilde bu hayvanların beslendiği yemlerden de yem örnekleri alınmıştır.

Van Firması 1-1: Lohman 1rkı tavuklardan birinci denemede 45, 50 ve 54. haftalık yaşta 10'ar adet toplamda 30 adet yumurta, aynı şekilde bu hayvanların beslendiği yemlerden de yem örnekleri alınmıştır. 
Van Firması 1-2: Lohman 1rkı tavuklardan birinci denemede 58., 63., ve 67. haftalık yaşta 10'ar toplam 30 adet yumurta örneği alınmıştır. Aynı şekilde bu hayvanların beslendiği yemlerden yem örnekleri alınmıştır.

\subsection{Yöntem}

\subsubsection{Deneme Planı ve Denemenin Yürütülmesi}

Denemede; yumurta kalite parametreleri, yumurta pigment skoru (RCF), Minolta a*, b* ve L* değerleri ile yumurtaların karoten ve vitamin içerik düzeylerinin (HPLC) belirlenmesi amacıyla, her işletmede $3 \mathrm{kez}$ ve her defada 10'ar yumurta alınarak firmaların her biri bir grup olarak isimlendirilmiştir. Her dönem toplam 4 grup kıyaslanmıştır. Örneklerin analizleri YYÜ Ziraat Fakültesi Zootekni Bölümü Yemler ve Hayvan Besleme Anabilim Dalı Laboratuvarı'nda yapılmıştır.

\subsubsection{Yumurta Sarısı Pigmentasyonunun Belirlenmesi}

Çalışmada yumurta sarısının pigmentasyonunun belirlenmesinde Roche skala renk skoru (RCF) ve Minolta kolorimetere cihazı ile iki farklı ölçüm metodu kullanılmıştır.

Roche Skalası renk Skoru (RCF): Yumurta sarısının ölçülmesinde yaygın olarak kullanılan pratik bir ölçüm skalasıdır. 1'den 15'e kadar farklı tonda sarı renkleri içeren sarı renk yelpazesidir.

\subsubsection{Yumurta Sarısının L* (parlaklık), a* (kırmızılık) ve b* (sarılık) Değerlerinin Ölçülmesi}

$L^{*}, a^{*}$ ve $b^{*}$ değerleri Chroma Meter, CR-400, Minolta, Osaka, Japan kolorimetre cihazı kullanılarak tespit edilmiştir. L* değeri; parlaklık olup maksimum değer " -100 " ve minimum " 0 " değeri siyahı göstermektedir. $\mathrm{a}^{*}$ değeri kırmızılığı gösterip; $(+100=$ kırmızı $)$ dan yeşile $(-100=$ yeşil $)$ ve $b^{*}$ değeri sarılık skalası olup sarıdan $(-100=$ mavi $)$ den sarıya $(100=$ sarı $)$ değerlerini göstermektedir (Skřivan ve ark.., 2015; Faitarone ve ark., 2016). Minolta L*, a* ve b* kayitları; Konica minolta CR400 cihazı ile sarı pigment ölçümleri yumurta sarısının 3 farklı bölgesinde alınan 3 okumanın ortalaması olarak alınmıştır.

\subsubsection{Yem ve Yumurtalarda HPLC ile Karoten ve Vitamin Analizleri}

Yem örneklerinin ekstraksiyonu: Her tekerrür için alınan yem örnekleri laboratuvar örneği haline getirilecek şekilde öğütülmüştür. $1 \mathrm{~g}$ laboratuvar numunesi cam tüpe konup $1.25 \mathrm{ml} \% 60 \mathrm{KOH}$ ve Pyrogallol (3 g pyrogallol $10 \mathrm{ml}$ etanolde çözdürülmüştür) (Surai ve ark., 1996) ile sabunlaştırmay1 gerçekleştirmek amacıyla 30 dakika $70{ }^{\circ} \mathrm{C}$ 'de su banyosunda tutulmuştur, sonra soğutulup $7 \mathrm{ml} \mathrm{NaCl}$ (\% 5) ve $5 \mathrm{ml}$ hekzan ilave edilerek karanlıkta 30 dakika buz dolu kap içerisinde bekletilmiştir. Daha sonra örneklerin üzerinde biriken hekzanda çözünen karoten ve vitaminler evaporasyon kabına aktarılmıştır. Hekzan ilavesi iki kez tekrarlandıktan sonra, ekstraktlar $65^{\circ} \mathrm{C}$ 'deki evaporasyon cihazında nitrojen gazı altında hekzan uzaklaştırılmıştır. Altta kalan örnek $(1: 1, \mathrm{v} / \mathrm{v})$ diklormetan ve metanolle tekrar çözdürülüp HPLC sistemine enjekte edilmiştir.

Yumurta örneklerinin ekstraksiyonu: $200 \mathrm{mg}$ yumurta örneğine önce \% $5 \mathrm{NaCl}$ 'den $0.7 \mathrm{ml}$ ardından $1 \mathrm{ml}$ etanol ilave edilmiştir. Daha sonra hekzan ile homojenize edilerek (önce $2 \mathrm{ml}$ ardından $1.8 \mathrm{ml}$ hekzan) santrifüjden geçirilmiş ( $8000 \mathrm{~g} / 10$ dakika), üstte biriken hekzan içinde çözünen karoten ve vitaminler evaporasyon kabına aktarılmıştır. Daha sonra yukarda yem örneklerinde verilenle aynı prosedüre devam edilmiştir (Surai, 2000; Surai ve ark., 2001; Surai ve Sparks, 2001).

Karotenlerin HPLC ile belirlenmesi Surai ve ark. (2001) metodu kullanılmıştır. Aynı ekstraktan $10 \mu 1$ HPLC sistemine enjekte edilmiş, Spherisorb tipi S3ODS2, 5- $\mu$ C18, ters faz kolon, $(25 \mathrm{~cm} \times 4.6$ $\mathrm{mm}$; Phase Separation, Clwyd, UK) asetonitril-metanol (85:15) ve asetonitril-diklormetan-metanol (70:20:10) mobil fazı kullanılarak deidore-detektör (DAD) ile $445 \mathrm{~nm}$ dalga boyunda okunmuştur.

Vitamin E ve Retinol'un HPLC ile belirlenmesi: $20 \mu 1$ ekstrakte edilmiş örnek HPLC sistemine injekte ettirilerek, 3- $\mu$ C18, ters-faz kolon, (15 cm x $4.6 \mathrm{~mm}$, Spherisorb ODS2, Phase Separation, Clwyd, UK) ve mobil fazı olarak metanol-distile su $(97: 3, \mathrm{v} / \mathrm{v})$ ve dakikada $1.05 \mathrm{ml}$ akış kullanılarak; excitation 295 
$\mathrm{nm}$ ve emission $330 \mathrm{~nm}$ olan Florasans detektörü ile $\alpha$ - tokoferol ve retinol standardı ile kalibre edilmiş HPLC'de sonuçlar belirlenmiştir (Surai ve ark., 1996).

\subsubsection{Karotenoidlerin Yemden Yumurtaya Geçişinin Hesaplanması}

Karotenoidlerin geçişi aşağıdaki formülle hesaplanmıştır (Karadas ve ark. 2006).

Karotenoidlerin depolanma etkinliği $=\frac{\text { Yumurtadan karotenoid üretimi }(A)}{\text { Yemden karetenoid üretimi }(B)} \times 100$

$A=$ Yumurta sarı ağırlı̆̆ $(\mathrm{g})$ x yumurta sarısı karotenoid konsantrasyonu $(\mu \mathrm{g} / \mathrm{g}) \times$ yumurta verimi $(\%)$ $\mathrm{B}=$ Yem tüketimi $(\mathrm{g} / \mathrm{gün} /$ hayvan$) \mathrm{x}$ yem karotenoid konsantrasyonu $(\mu \mathrm{g} / \mathrm{g})$

\section{3. İstatistiksek Analiz}

Ele alınan özellikler bakımından tanımlayıcı istatistikler, Ortalama \pm Standart hata olarak verilmiştir. Bu özellikler bakımından ırklara göre farklılık olup olmadığını belirlemek üzere, Tek Yönlü Kovaryans Analizi (One-way ANCOVA) yapılmıştır. Irklar arası farklılığa etkili olabileceği düşünülen faktörlerden Kanatlı yaşı (Poultry age) kovaryet faktör olarak alınmıştır. Varyete, Lokasyonu (Test sites: Van ve Muş) kapsadığından, Lokasyon modele dahil edilememiştir. Böylece, Dönem ve Varyete faktörü ile birlikte, Kanatlı yaşı faktörü (kovaryet faktör alınarak) modele dahil edilmiştir. Faktör sevilerine göre dengeli dağılım olmadığından, interaksiyon (etkileşim) etkisine bakılamamış ve yalnızca ana etkiler dikkate alınarak analizler icra edilmiştir. Varyans analizlerini takiben, farklı grupları belirlemede Duncan çoklu karşılaştırma testi yapılmıştır. Hesaplamalarda istatistik önemlilik (anlamlılık) düzeyi \%5 olarak alınmış ve hesaplamalar için SAS (ver: 9.4) istatistik paket programı kullanılmıştır.

\section{Bulgular}

Çalışmada ele alınan özellikler için modele dahil edilen faktörlerin ana etkilerine ilişkin sonuçlar Çizelge 1'de verilmiştir. Çizelge 1'de görüldüğü üzere; modele kovaryet faktör olarak dahil edilen kanatlı yaşının etkisi, tüm özellikler için istatistik olarak önemli bulunmazken, özelliklerin büyük çoğunluğunda, dönem etkisi istatistik olarak önemli bulunmuştur. $\mathrm{Bu}$ nedenle, varyete (irk) karşılaştırmaları dönemlerde ayrı ayrı yapılmış ve elde edilen sonuçlar tablolar halinde sunulmuştur.

Çizelge 1. Özellikler için Dönem, Yaş ve Varyete etkileri

\begin{tabular}{lccc}
\hline \multirow{2}{*}{ Özellikler } & \multicolumn{3}{c}{ Etilere ilişkin p değerleri } \\
\cline { 2 - 4 } & Dönem & Varyete & Hafta \\
\hline Yumurta ă̆ırlı̆̆1 & 0.003 & 0.015 & 0.895 \\
Kabuk ağırlığ & 0.006 & 0.299 & 0.172 \\
Sarı ağırlı̆1 & 0.778 & 0.065 & 0.833 \\
Ak ağırlığ1 & 0.001 & 0.019 & 0.605 \\
Sarı ağırlık & 0.010 & 0.904 & 0.697 \\
Ak ağırlık & 0.019 & 0.487 & 0.339 \\
Kabuk ağırlık & 0.111 & 0.001 & 0.097 \\
Roche skalas1 & 0.001 & 0.004 & 0.146 \\
Minolta L & 0.692 & 0.931 & 0.257 \\
Minolta a & 0.007 & 0.856 & 0.066 \\
Minolta b & 0.139 & 0.360 & 0.055 \\
Vitamin A (retinol) & 0.001 & 0.986 & 0.983 \\
Gamatokotrienol & 0.001 & 0.000 & 0.779 \\
Alfatokotrienol & 0.150 & 0.000 & 0.500 \\
\hline
\end{tabular}


Çizelge 1. Özellikler için Dönem, Yaş ve Varyete etkileri (devam)

\begin{tabular}{lccc}
\hline \multirow{2}{*}{ Özellikler } & \multicolumn{3}{c}{ Etilere ilişkin p değerleri } \\
\cline { 2 - 4 } & Dönem & Varyete & Hafta \\
\hline Deltatokoferol & 0.001 & 0.000 & 0.349 \\
Gamatokoferol & 0.001 & 0.000 & 0.879 \\
Alfatokoferol & 0.001 & 0.000 & 0.581 \\
Toplam vitamin E & 0.001 & 0.000 & 0.766 \\
Toplam karoten & 0.001 & 0.000 & 0.733 \\
Lutein & 0.001 & 0.008 & 0.058 \\
Zeaksantin & 0.175 & 0.000 & 0.754 \\
Ciszeaksantin & 0.001 & 0.158 & 0.615 \\
Kantaksantin & 0.017 & 0.009 & 0.053 \\
Tanimlanamayan karoten & 0.004 & 0.001 & 0.174 \\
Apoester & 0.006 & 0.001 & 0.522 \\
Anhidrolutein & 0.001 & 0.001 & 0.180 \\
\hline
\end{tabular}

\subsection{Yumurta Sarı Renginin Roche Skalası ve Minolta Cihazı ile Ölçüm Ortalamaları}

Yumurta sarı roche skala sonuçları ve minolta cihazı $\left(L^{*}, a^{*} v e b^{*}\right)$ değerleri Çizelge 2'de verilmiştir.

Çizelge 2'de 1. dönemde Roche skalası sonuçları incelendiğinde Van firmasına ait 45. haftalık yaştaki Lohman 1rkı tavuklara ait yumurtaların yumurta sarı pigment değerlerinin en yüksek olduğu bunu Lohman 58 haftalık yaş tavuklarının yumurta sarılarının takip ettikleri ve Lohman 45-58 hafta yaş yumurta tavuğu Roche skalası sonuçlarının Muş firmaları tarafından yetiştirilen Tinted rrkı 44 . ve Novagen 32. hafta yaştaki yumurta tavuğu yumurta sarılarından önemli ölçüde yüksek olduğu $(\mathrm{P}<0.05)$ saptanmışken; aynı yemle beslendiklerinden Lohman 45 ve 58. hafta yaş grupları arasında farklılık saptanmamıştır $(\mathrm{P}>0.05)$. Tinted 1rkı 44 ve Novagen 32 Hafta yaştaki yumurtaların Roche skalaları arasında önemli düzeyde farklılık saptanmıştır $(\mathrm{P}<0.05)$. İkinci dönem sonuçları incelendiğinde 50 haftalık yaştaki Lohman ırkı tavuklara ait yumurta sarılarının Roche skalası Muş ilinde yetiştiriciliği yapılan Novagen 37. Haftalık yaştaki yumurta tavuklarının yumurta sarısı Roche skalası ile benzer bulunmuşken, diğer grupların yumurta sarılarına göre önemli ölçüde yüksek oranda pigment skoru göstermiştir $(\mathrm{p}<0.05)$. Roche skalası 3. dönem sonuçları incelendiğinde Van firması yumurtaları (Lohman 54- 67. Hafta) Muş firması (Tinted 53 ve Novagen 43) yumurtalarıla karşılaştırıldığında önemli düzeyde yüksek Roche skala değeri göstermiştir (Çizelge 2).

Roche skalası değerleri bir bütün olarak değerlendirildiğinde yapılan ölçümlerde en düşük değer 10.45 ve en yüksek skala değeri 12.50 olarak kayıt edilmiştir. Avrupa ve Asya kıtasındaki tüketicilerin tercih ettikleri yumurta sarısı RCF değerinin 10 ile 14 arasında olduğu (Galobart ve ark., 2004) dolayısıyla elde edilen bu değerler, tüketiciler tarafından kabul edilebilir skala aralığında olduğu görülmektedir. Bu bulgular ayrıca Lokaewmanee ve ark. (2010) tarafindan 25 haftalık yaşta Charoen Pokphand 1rkı yumurtacı tavuk mısır soya temelli rasyonlara ilave ettikleri Marigol çiçeği ekstraktı, kırmızı biber ekstraktı ve bu ikisinin kombinasyonunu ile beslediği yumurta tavuklarının yumurta sarısı RCF değerlerini sırası ile 8.64; 11.47 ve 12.17 olarak bildirdiği bulgular ile de benzerlik göstermektedir. Bu bulgular ayrıca; Şamlı ve ark. (2005), Karadas ve ark. (2006), Macit ve ark. (2007) ve Yenice ve ark. (2007),'nin değerleri ile paralellik göstermektedir. Yine Karageçili ve Karadaş (2015) tarafindan Lohman 1rk1 33., 43. ve 53. hafta yaştaki yumurta tavuk RCF değerleri sırasıyla 11.05, 12.35 ve 12.25 olduğu bildirilmiş ve elde edilen bulguların bu çalışma ile yakın benzerlik gösterdiği saptanmıştır.

Minolta L* değerleri 1. dönemde Muş'tan alınan örneklerde Van'dan alınan örneklerden önemli ölçüde yüksek olduğu saptanmıştır $(\mathrm{p}<0.05)$. Bu farklılığın 2. dönemde değişim gösterdiği Van firmalarının yumurta örneklerinde parlaklığın iyileştiği, Muş Novagen 43 firma yumurtalarının 2. dönemde Van firmasındaki yumurtalara göre önemli ölçüde düşük parlaklık değeri gösterdikleri ve parlaklığın 3. dönemde yine Van (Lohman 67) firmasındaki yumurtalarda Muş firmalarındaki yumurtalara göre (Tinted 53 ve Novagen 41) önemli ölçüde daha yüksek olduğu saptanmıştır $(p<0.05)$.

Minolta a* değerleri 1. dönemde Van'dan alınan örneklerde (Lohman 45-48 hafta yaşta) Muş ilinden alınan yumurta örneklerinden (Tinted 44 ve Novagen 32) önemli ölçüde daha kırmızı olduğu 
saptanmıştır. Bu farklılığın 2. dönemde değişim göstererek Muş Novagen 37. hafta yaştaki tavuk yumurtalarının Tinted ve Lohman 63 haftalık yaştaki tavuk yumurtalarının sarısının kırmızılık değerinden ( $a^{*}$ ) önemli ölçüde yüksek olduğu saptanmıştır $(p<0.05)$. 3. dönemde yine Van Lohman 54. hafta tavuk yumurtalarının sarı (a*) değeri Van Lohman 67. Hafta ve Muş Novagen 41 hafta ile benzer, ancak Muş Tinted ırkı yumurta sarısından önemli ölçüde daha yüksek değer gösterdikleri saptanmıştır $(\mathrm{P}<0.05)$.

Minolta $b^{*}$ değerleri 1. Dönemde kırmızılık değerlerinin aksine Tinted 44 yaş grubu yumurta tavuklarından alınan örneklerin, Van'dan alınan örneklerden (Lohman 45-58 haftalık yaşta) önemli ölçüde daha yüksek sarı pigmente sahip olduğu, diğer gruplar arasında farklılığın önemsiz olduğu gözlenmektedir. 2. dönemde $b *$ değeri açısından alınan yumurta örnekleri arasında önemli bir farklılığa rastlanmamıştır $(\mathrm{P}>0.05)$. 3. dönemde yine Van (Lohman 54) yumurtalarının $\mathrm{b}^{*}$ değerinin $\mathrm{a}^{*}$ değeri ile benzer şekilde Muş yumurtalarından (Tinted 53 ve Novagen 41 haftalık yaş) önemli ölçüde daha yüksek olduğu saptanmıştır $(\mathrm{P}<0.05)$.

Minolta değerleri bir bütün olarak incelendiğinde en düşük L* değeri 46.60 en yüksek L* değeri 57.40 kayıt edilmiş olup Lokaewmanee ve ark. (2010) tarafından yumurtacı tavuk mısır soya temelli rasyonlara ilave ettikleri Marigol çiçeği ekstrakt1, kırmızı biber ekstraktı ve bu ikisinin kombinasyonunun yumurta sarısı L* değeri sırasıyla 45.19 Misır soya temelli kontrol rasyonu, kırmızı biber ekstraktı ilave edilende 43.58, Kırmızı biber ekstraktı + marigold ekstraktı ilave edilen grupta ise 42.31 olarak bildirilmiştir. Elde edilen bulgular kontrol grubu ile Lohman 1rk1 45. Hafta yumurta sarısı $L^{*}$ değeri paralellik göstermekle beraber, diğer dönem ve ırklarda $L^{*}$ değeri bu çalışmadan 10 birim daha düşük çıkmış ve benzerlik göstermemektedir. Bu bulguların farklılığı 1rk ve yaş farklılığı yanı sıra yemlerin içindeki sentetik ve doğal katkıların farklılığından da olabileceği sonucuna varılmıştır.

Çizelge 2. Yumurta sarısı Roche skalası ve Minolta L*, a* ve b* ölçüm ortalamaları ve standart hataları

\begin{tabular}{lllllll}
\hline \multirow{2}{*}{ Dönem } & \multirow{2}{*}{ Irk } & \multirow{2}{*}{ Yaş } & Roche & \multicolumn{3}{c}{ Minolta } \\
\cline { 5 - 6 } & Tinted & 44 & $11.10 \pm 0.21^{\mathrm{b}}$ & $55.83 \pm 1.16^{\mathrm{a}}$ & $5.35 \pm 0.36^{\mathrm{b}}$ & $41.14 \pm 1.94^{\mathrm{a}}$ \\
& Novagen & 32 & $10.45 \pm 0.25^{\mathrm{c}}$ & $57.40 \pm 0.92^{\mathrm{a}}$ & $5.35 \pm 0.70^{\mathrm{b}}$ & $38.03 \pm 0.75^{\mathrm{ab}}$ \\
& Lohman & 45 & $11.85 \pm 0.13^{\mathrm{a}}$ & $46.60 \pm 1.56^{\mathrm{b}}$ & $7.37 \pm 0.20^{\mathrm{a}}$ & $33.83 \pm 1.18^{\mathrm{b}}$ \\
& Lohman & 58 & $11.45 \pm 0.17^{\mathrm{ab}}$ & $47.44 \pm 1.62^{\mathrm{b}}$ & $7.40 \pm 0.40^{\mathrm{a}}$ & $35.82 \pm 1.67^{\mathrm{b}}$ \\
\hline \multirow{3}{*}{2} & Tinted & 49 & $11.55 \pm 0.16^{\mathrm{c}}$ & $52.42 \pm 0.87^{\mathrm{ab}}$ & $6.55 \pm 0.45^{\mathrm{c}}$ & $37.89 \pm 1.48$ \\
& Novagen & 37 & $12.45 \pm 0.19^{\mathrm{ab}}$ & $49.64 \pm 1.36^{\mathrm{b}}$ & $8.74 \pm 0.44^{\mathrm{a}}$ & $35.50 \pm 0.94$ \\
& Lohman & 50 & $12.50 \pm 0.16^{\mathrm{a}}$ & $53.41 \pm 0.82^{\mathrm{a}}$ & $8.25 \pm 0.41^{\mathrm{ab}}$ & $35.56 \pm 0.89$ \\
& Lohman & 63 & $11.81 \pm 0.37^{\mathrm{bc}}$ & $53.78 \pm 0.53^{\mathrm{a}}$ & $7.16 \pm 0.46^{\mathrm{bc}}$ & $38.27 \pm 0.58$ \\
\hline \multirow{3}{*}{3} & Tinted & 53 & $10.90 \pm 0.10^{\mathrm{b}}$ & $50.03 \pm 1.11^{\mathrm{b}}$ & $7.07 \pm 0.32^{\mathrm{b}}$ & $36.18 \pm 1.04^{\mathrm{b}}$ \\
& Novagen & 41 & $10.75 \pm 0.17^{\mathrm{b}}$ & $48.75 \pm 1.39^{\mathrm{b}}$ & $7.61 \pm 0.55^{\mathrm{ab}}$ & $36.58 \pm 1.24^{\mathrm{b}}$ \\
& Lohman & 54 & $12.30 \pm 0.20^{\mathrm{a}}$ & $53.71 \pm 0.94^{\mathrm{a}}$ & $7.92 \pm 0.48^{\mathrm{ab}}$ & $40.41 \pm 0.92^{\mathrm{a}}$ \\
& Lohman & 67 & $12.15 \pm 0.30^{\mathrm{a}}$ & $50.79 \pm 1.21^{\mathrm{ab}}$ & $7.92 \pm 0.49^{\mathrm{a}}$ & $37.91 \pm 1.34^{\mathrm{ab}}$ \\
\hline
\end{tabular}

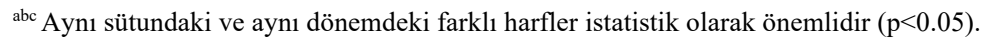

\subsection{Yumurta Sarısı Toplam ve Bireysel Karoten İçerikleri}

Alınan yumurta örneklerinde toplam karoten içerikleri Roche skalası ve Minolta $b^{*}$ değerleri ile paralellik gösterdiği (Çizelge 3); 1. dönemde toplam karoten içeriğinin en yüksek Tinted 1 rkı 44 haftalık yaştaki tavuk yumurtalarında $21.20 \mu \mathrm{g} / \mathrm{g}$ seviyesinde bunu Lohman 45 . ve Lohman 58 haftalık yaşta tavuk yumurtalarının $19.21 \mathrm{ve} 19.11 \mu \mathrm{g} / \mathrm{g}$ takip ettiği ve bu gruplar arasında önemli bir farklılık olmadığ ancak Novagen ırkı 32 haftalık yaşta tavuk yumurtalarının toplam karoten içeriğinin tüm gruplardan önemli ölçüde düşük olduğu gözlenmektedir $(\mathrm{P}<0.05)$.

Elde edilen bu bulgular; Karadas ve ark. (2006) tarafından yapılan çalışmadaki \% 2 oranında yonca ekstraktı ilave edilen buğday temelli rasyonlar ile beslenen bıldırcın yumurtalarının toplam karoten içeriğinin $22.4 \mu \mathrm{g} / \mathrm{g}$ olarak ölçüldüğü sonuç ile benzerlik gösterdiği görülmüşken, rasyona \% 0.02 oranında marigold ekstraktı ilave edildiğinde yumurtaların toplam karoten içeriğinin $39.0 \mu \mathrm{g} / \mathrm{g}$ olduğu değer ile benzerlik göstermediği görülmektedir. Aynı şekilde Karageçili ve Karadaş (2015) tarafindan Lohman 1rk1 33, 43 ve 53 haftalık yaştaki tavukların yumurtalarındaki toplam karoten 
içeriğinin sırasıyla $19.93,16.85$ ve $18.14 \mu \mathrm{g} / \mathrm{g}$ olduğu bildirilmiş ve elde edilen bulguların bu çalışma ile paralel olduğu görülmektedir.

Çizelge 3. Yumurta sarısı toplam karoten içeriği $(\mu \mathrm{g} / \mathrm{g})$ ortalamaları ve standart hataları

\begin{tabular}{llcc}
\hline Dönem & Irk & $\begin{array}{c}\text { Yaş } \\
(\text { Hafta })\end{array}$ & Toplam karoten miktarı $(\mu \mathrm{g} / \mathrm{g})$ \\
\hline \multirow{4}{*}{1} & Tinted & 44 & $21.20 \pm 0.76^{\mathrm{a}}$ \\
& Novagen & 32 & $12.48 \pm 0.77^{\mathrm{b}}$ \\
& Lohman & 45 & $19.21 \pm 1.10^{\mathrm{a}}$ \\
& Lohman & 58 & $19.11 \pm 0.71^{\mathrm{a}}$ \\
\hline & Tinted & 49 & $17.95 \pm 1.61$ \\
& Novagen & 37 & $14.98 \pm 1.60$ \\
& Lohman & 50 & $16.77 \pm 0.35$ \\
3 & Lohman & 63 & $15.72 \pm 0.87$ \\
\hline & Tinted & 53 & $18.77 \pm 1.13^{\mathrm{ab}}$ \\
& Novagen & 41 & $22.19 \pm 0.61^{\mathrm{b}}$ \\
& Lohman & 54 & $22.24 \pm 1.11^{\mathrm{a}}$ \\
\hline
\end{tabular}

${ }^{\mathrm{ab}}$ Aynı sütundaki ve aynı dönemdeki farklı harfler istatistik olarak önemlidir $(\mathrm{p}<0.05)$.

Ticari yumurtaların bireysel karoten içerikleri genel olarak değerlendirildiğinde ülkemizde piyasaya sürülen yumurtalarda minimum 3.40 ve maksimum $8.60(\mu \mathrm{g} / \mathrm{g})$ olmak üzere ortalama 5.5 $(\mu \mathrm{g} / \mathrm{g})$ Lutein ve minimum 4.93- maksimum $8.00 \mu \mathrm{g} / \mathrm{g}$ olmak üzere ortalama $6.32 \mu \mathrm{g} / \mathrm{g}$ oranında zeaksantin toplamda 11.88 oranında doğal karoten içerdikleri görülmektedir (Çizelge 4). Ülkemizde yumurta tavuk yemleri genellikle Misır-Soya temelli olduklarından doğal olarak lutein-zeaksantin ağırlıklı karotenler yumurtalarda baskın olarak görülmektedir. Sentetik karotenlerden kantaksantin ve apoester'e baktığımızda, sarı pigmentlerin büyük çoğunluğunun lutein ve zeaksantin gibi doğal karotenlerden karşılandığı, çok az miktarda sarı pigment olarak apoester kullanıldığı, bunun da 0.42 $0.99 \mu \mathrm{g} / \mathrm{g}$ 'nın yumurtaya aktarıldığı, kırmızı pigment olarak genellikle kantaksantin kullanıldığı bunun sonucu olarak da yumurtada 2.83-4.29 $\mu \mathrm{g} / \mathrm{g}$ düzeyinde kantaksantin biriktiği görülmektedir.

Çizelge 4. Yumurta sarısı bireysel karoten miktarlarının ( $\mu \mathrm{g} / \mathrm{g})$ ortalamaları ve standart hataları

\begin{tabular}{|c|c|c|c|c|c|c|c|c|c|}
\hline Dönem & Irk & Yaş & $\begin{array}{c}\text { Tanımlanamayan } \\
\text { Karoten }\end{array}$ & Lutein & Zeaksantin & $\begin{array}{c}\text { Cis- } \\
\text { zeaksantin }\end{array}$ & Kantaksantin & Apoester & $\begin{array}{l}\text { Anhidro- } \\
\text { lutein }\end{array}$ \\
\hline 1 & Tinted & 44 & $0.32 \pm 0.01^{\mathrm{a}}$ & $8.60 \pm 0.33^{\mathrm{a}}$ & $7.92 \pm 0.33^{\mathrm{a}}$ & $0.80 \pm 0.55^{\mathrm{a}}$ & $2.85 \pm 0.14^{\mathrm{b}}$ & $0.42 \pm 0.03^{b}$ & $0.29 \pm 0.02^{\mathrm{a}}$ \\
\hline 1 & Novagen & 32 & $0.03 \pm 0.01^{\mathrm{c}}$ & $3.40 \pm 0.26^{\mathrm{c}}$ & $4.93 \pm 0.35^{\mathrm{c}}$ & $0.57 \pm 0.50^{\mathrm{b}}$ & $2.86 \pm 0.22^{\mathrm{b}}$ & $0.68 \pm 0.06^{\mathrm{a}}$ & N/A * \\
\hline 1 & Lohman & 45 & $0.18 \pm 0.01^{\mathrm{b}}$ & $5.74 \pm 0.53^{\mathrm{b}}$ & $8.00 \pm 0.39^{\mathrm{a}}$ & $0.87 \pm 0.87^{\mathrm{a}}$ & $3.66 \pm 0.27^{\mathrm{a}}$ & $0.71 \pm 0.04^{\mathrm{a}}$ & $0.04 \pm 0.01^{\mathrm{b}}$ \\
\hline 1 & Lohman & 58 & $0.04 \pm 0.01^{\mathrm{c}}$ & $8.01 \pm 0.33^{\mathrm{a}}$ & $5.98 \pm 0.23^{\mathrm{b}}$ & $0.93 \pm 0.79^{\mathrm{a}}$ & $3.47 \pm 0.23^{\mathrm{ab}}$ & $0.63 \pm 0.07^{\mathrm{a}}$ & $0.04 \pm 0.04^{\mathrm{b}}$ \\
\hline 2 & Tinted & 49 & $0.25 \pm 0.04$ & $4.74 \pm 0.29$ & $8.00 \pm 0.62^{\mathrm{a}}$ & $0.52 \pm 0.49$ & $3.46 \pm 0.15$ & $0.63 \pm 0.03^{c}$ & $0.35 \pm 0.03$ \\
\hline 2 & Novagen & 37 & N/A* & $5.24 \pm 0.61$ & $4.10 \pm 0.51^{\mathrm{c}}$ & $0.56 \pm 0.07$ & $4.09 \pm 0.48$ & $0.99 \pm 0.12^{\mathrm{a}}$ & N/A* \\
\hline 2 & Lohman & 50 & N/A* & $5.63 \pm 0.17$ & $5.53 \pm 0.16^{\mathrm{b}}$ & $0.58 \pm 0.03$ & $4.16 \pm 0.15$ & $0.86 \pm 0.04^{\mathrm{ab}}$ & N/A* \\
\hline 2 & Lohman & 63 & N/A* & $5.41 \pm 0.29$ & $5.61 \pm 0.36^{\mathrm{b}}$ & $0.58 \pm 0.06$ & $3.44 \pm 0.19$ & $0.69 \pm 0.05^{\mathrm{bc}}$ & N/A* \\
\hline 3 & Tinted & 53 & $0.04 \pm 0.02$ & $3.67 \pm 0.65^{b}$ & $5.39 \pm 0.93$ & $0.34 \pm 0.06$ & $2.83 \pm 0.50$ & $0.55 \pm 0.10$ & $0.42 \pm 0.09$ \\
\hline 3 & Novagen & 41 & $0.06 \pm 0.03$ & $5.43 \pm 0.69^{\mathrm{ab}}$ & $5.93 \pm 0.76$ & $0.53 \pm 0.07$ & $3.61 \pm 0.55$ & $0.78 \pm 0.13$ & $0.22 \pm 0.01$ \\
\hline 3 & Lohman & 54 & $0.01 \pm 0.01$ & $5.30 \pm 0.71^{\mathrm{ab}}$ & $6.53 \pm 0.87$ & $0.57 \pm 0.13$ & $4.29 \pm 0.95$ & $0.98 \pm 0.27$ & $0.90 \pm 0.43$ \\
\hline 3 & Lohman & 67 & $0.07 \pm 0.04$ & $6.30 \pm 0.78^{\mathrm{a}}$ & $7.97 \pm 0.99$ & $0.62 \pm 0.10$ & $3.59 \pm 0.47$ & $0.64 \pm 0.09$ & $0.31 \pm 0.17$ \\
\hline
\end{tabular}

${ }^{\text {abc }}$ Aynı sütundaki ve dönemdeki farklı harfler istatistik olarak önemlidir $(\mathrm{p}<0.05)$.

${ }^{*} \mathrm{~N} / \mathrm{A}$ : Not avaible.

\subsection{Yumurta Sarısı Vitamin A ve Vitamin E içeriği}

Farklı dönemlerde farklı ticari yumurtacı ırkların yumurtalarının vitamin A (retinol) ve vitamin E içerikleri Çizelge 5'te verilmiştir.

Çizelge 5 incelendiğinde görüleceği gibi vitamin A (retinol) içeriği bakımından 1. dönemde Tinted 44. hafta yaştaki yumurtaların haricinde yaş ve irklar bakımından farklılık saptanmamıştır $(\mathrm{P}>0.05)$.

Yumurtaların 1. dönemde Vitamin E içeriği sadece Novagen 32 haftalık yumurtalarda önemli düzeyde düşük kalmış ve diğer gruplardaki yumurtalar arasında farklılık saptanmamıştır. İkinci 
dönemde vitamin E içeriğinin sırasıyla 97.69>73.94 $\geq 72.67>31.99 \mu \mathrm{g} / \mathrm{g}$ olduğu ve en yüksek değer Tinted 1rk1 yumurtalarda görülürken bunu Lohman 50 ve Lohman 63. haftalık yaştaki tavuklara ait yumurtalar izlemiştir. En düşük vitamin E içeriği ise Novagen 1rk1 37 haftalık yaştaki tavuklardan elde edilen yumurtalarda saptanmıştır $(\mathrm{P}<0.05)$. Üçüncü dönemde ise Lohman 54 ve 67. Hafta yumurtalarda diğer yumurtalardan önemli ölçüde yüksek olduğu görülmektedir $(\mathrm{P}<0.05)$.

$\mathrm{Bu}$ çalışmada vitamin A (Retinol) içerikleri genel olarak değerlendirildiğinde yumurtaların retinol içeriklerinin 3-5 $\mu \mathrm{g} / \mathrm{g}$ olduğu ve bu sonuçlarının 33. hafta Lohman ticari yumurta sonuçları olan $3.96 \mu \mathrm{g} / \mathrm{g}$ ve 53 . Hafta $5.23 \mu \mathrm{g} / \mathrm{g}$ sonuçları ile tam bir paralellik gösterdiği (Karageçili ve Karadaş 2015) görülmektedir.

Vitamin E sonuçları genel olarak değerlendirildiğinde; yine retinol sonuçları gibi Lohman 4558. Hafta sonuçları 82-83 $\mu \mathrm{g} / \mathrm{g}$ sonuçları daha önce yapılan Lohman 33-43. Hafta sonuçları ile (85-87 $\mu \mathrm{g} / \mathrm{g}$ ) ile büyük bir benzerlik gösterdiği aynı şekilde Lohman 54-67 hafta yumurtalarının vitamin E içeriği 153-145 $\mu \mathrm{g} / \mathrm{g}$ daha önce Karageçili ve Karadaş (2015) tarafından yapılan çalışmada bildirilen 53. hafta Lohman yumurtalarının vitamin E içeriği olan 140.68 değeri ile paralel sonuçlar elde edilmiştir.

Çizelge 5. Yumurta Sarısı Vitamin A ve Vitamin E $\mu \mathrm{g} / \mathrm{g}$ içeriği

\begin{tabular}{clccc}
\hline Dönem & Irk & $\begin{array}{c}\text { Yaş } \\
(\text { Hafta })\end{array}$ & $\begin{array}{c}\text { Vitamin A } \\
(\text { Retinol) }\end{array}$ & Vitamin E \\
\hline 1 & Tinted & 44 & $4.06 \pm 0.22^{\mathrm{a}}$ & $74.46 \pm 2.71^{\mathrm{a}}$ \\
1 & Novagen & 32 & $3.31 \pm 0.1^{\mathrm{b}}$ & $23.95 \pm 1.84^{\mathrm{b}}$ \\
1 & Lohman & 45 & $3.04 \pm 0.22^{\mathrm{b}}$ & $82.88 \pm 4.08^{\mathrm{a}}$ \\
1 & Lohman & 58 & $3.27 \pm 0.22^{\mathrm{b}}$ & $83.86 \pm 3.59^{\mathrm{a}}$ \\
\hline 2 & Tinted & 49 & $3.62 \pm 0.30$ & $97.69 \pm 4.48^{\mathrm{a}}$ \\
2 & Novagen & 37 & $3.60 \pm 0.49$ & $31.99 \pm 3.47^{\mathrm{c}}$ \\
2 & Lohman & 50 & $3.78 \pm 0.16$ & $72.67 \pm 3.21^{\mathrm{b}}$ \\
2 & Lohman & 63 & $3.37 \pm 0.19$ & $73.94 \pm 3.93^{\mathrm{b}}$ \\
\hline 3 & Tinted & 53 & $4.08 \pm 0.24$ & $74.65 \pm 3.66^{\mathrm{b}}$ \\
3 & Novagen & 41 & $5.02 \pm 0.67$ & $81.00 \pm 9.85^{\mathrm{b}}$ \\
3 & Lohman & 54 & $5.05 \pm 0.18$ & $153.04 \pm 8.19^{\mathrm{a}}$ \\
3 & Lohman & 67 & $5.25 \pm 0.19$ & $145.39 \pm 5.27^{\mathrm{a}}$ \\
\hline
\end{tabular}

${ }^{\text {abc }}$ Aynı sütundaki ve dönemdeki farklı harfler istatistik olarak önemlidir $(\mathrm{p}<0.05)$.

\subsection{Yemlerin Toplam ve Bireysel Karoten İçerikleri}

Yemlerdeki toplam karoten ortalamaları ve standart hataları Çizelge 6'da verilmiştir . Birinci dönem yemlerde en yüksek toplam karoten içeriği Van'da yetiştirilen Lohman ırkı yumurtacı tavukların yemlerinde saptanmıştır $(\mathrm{p}<0.05)$.

Çizelge 6. Yemlerdeki toplam karoten miktarlarının $(\mu \mathrm{g} / \mathrm{g})$ ortalamaları ve standart hataları

\begin{tabular}{ccc}
\hline Dönem & Yem & Toplam Karoten $(\mu \mathrm{g} / \mathrm{g})$ \\
\hline 1 & Tinted 44 & $12.28 \pm 0.75^{\mathrm{b}}$ \\
1 & Novagen 32 & $9.87 \pm 0.25^{\mathrm{c}}$ \\
1 & Lohman 45 $5.28 \pm 0.22^{\mathrm{a}}$ \\
1 & Lohman 58 & $15.28 \pm 0.22^{\mathrm{a}}$ \\
\hline 2 & Tinted 49 & $13.62 \pm 2.32$ \\
2 & Novagen 37 & $10.24 \pm 2.64$ \\
2 & Lohman 50 & $8.89 \pm 0.48$ \\
2 & Lohman 63 & $11.90 \pm 0.52$ \\
\hline 3 & Tinted 53 & $11.54 \pm 0.24^{\mathrm{a}}$ \\
3 & Novagen 41 & $8.92 \pm 0.57^{\mathrm{b}}$ \\
3 & Lohman 54 & $11.86 \pm 0.52^{\mathrm{a}}$ \\
3 & Lohman 67 & $11.90 \pm 0.52^{\mathrm{a}}$ \\
\hline
\end{tabular}

\footnotetext{
${ }^{\text {ab }}$ Aynı sütundaki ve dönemdeki farklı harfler istatistik olarak önemlidir $(\mathrm{p}<0.05)$.
} 
Ticari yumurta tavukları yemlerinde kullanılan yemlerin toplam karoten içeriği dönemlere göre incelendiğinde Novagen 32 hafta tavuk yemlerinin diğer yemlere göre önemli düzeyde düşük oranda karoten içerdiği; 2. Dönemde bunun iyileştirildiği ( $\mathrm{P}>0.05)$, ancak son dönemde aynı durumun tekrar gözlendiği $(\mathrm{P}<0.05)$ saptanmıştır. Yemlerin toplam karoten içeriği ile ilgili elde edilen bulgular Karageçili ve Karadaş (2015) tarafından ticari Lohman yumurtacı tavuk ırklarının 33., 43. ve 53. hafta yemlerinde 5.37, 7.50, $9.36 \mu \mathrm{g} / \mathrm{g}$ ile Hy-line yumurtac1 tavuk 1rk1 48., 58. ve 68. hafta yemlerinde, toplam karoten miktarı 5.39, 6.56, ve $9.85 \mu \mathrm{g} / \mathrm{g}$ olarak bildirilen çalışma sonuçlardan bir miktar yüksek olmakla beraber paralellik göstermektedir.

Yemlerin bireysel karoten miktarları Çizelge 7'de verilmiştir. Çizelge 7 incelendiğinde de görüldüğ̈̈ gibi yemlerde tanımlanamayan karoten haricinde lutein, zeaksantin, kantaksantin, apoester ve $\beta$-karoten olmak üzere 5 bilinen bireysel karoten tespit edilmiştir. Yumurtada bu karotenlerin " $\beta$ Karoten" hariç, hepsi tespit edilmiştir. B-karoten provitamin A olması nedeniyle muhtemelen tavuk metabolizmasında A vitaminine dönüştüğünden yumurtada saptanamamıştır.

Her 3 dönem yemleri doğal ve sentetik karotenler açısından incelendiğinde 8-15 $\mu \mathrm{g} / \mathrm{g}$ toplam karotenin büyük çoğunluğu 8-11 $\mu \mathrm{g} / \mathrm{g}$ karotenin doğal karotenler (lutein + zeaksantin) ve sadece 2-3 $\mu \mathrm{g} / \mathrm{g}$ 'nın sentetik apoester + kantaksantin karoten içerdiği gözlenmektedir.

Avrupa Birliği tarafindan kanatlı ve balık yemlerinde renk pigmentlerinin kullanımı 70/524/EEC as E-161g yönetmelik ile denetim altına alınmıştır. Bu yönetmelik kapsamında sentetik kırmızı ve sarı renk pigmentlerinin $0-8 \mathrm{mg} / \mathrm{kg}$ toplamlarının da $10-15 \mathrm{mg} / \mathrm{kg}$ miktarlarında yemlere ilave edilebileceği belirtilmiştir (EFSA, 2014).

$\mathrm{Bu}$ çalışmada sentetik sarı ve kırmızı pigmentlerin yemlerdeki seviyelerinin $(2-3 \mu \mathrm{g} / \mathrm{g})$ oldukça düşük düzeyde olduğu ve yemdeki karotenlerin \% 70-80'nin doğal karoten içerdiği bununda karma yemlerin mısır temelli olmasından kaynaklandığı bu çalışma ile bir kez daha doğrulanmıştır.

Novagen tavuklarının beslendiği yemlerde bulunan luteinin \% 20.63'ü, zeaksantinin \% 16.45'i, kantaksantinin \% 49.30'u, apoesterin \% 6.83'ü yumurtada depolanmıştır. Tinted tavuklarının beslendiği yemlerde bulunan luteinin \% 11.79'u, zeaksantinin \% 49.10'u, kantaksantinin \% 65.38'i, apoesterin \% 16.90'ı yumurtada depolanmıştır. Lohman (45-50-54 haftalık yaş) tavuklarının beslendiği yemlerde bulunan luteinin \% 17.97'si, zeaksantinin \% 17.00'1, kantaksantinin \% 61.67'si, apoesterin \% 10.41'i yumurtada depolanmıştır. Lohman (58-63-67 haftalık yaş) tavuklarının beslendiği yemlerde bulunan luteinin \% 25.64'ü, zeaksantinin \% 20.23'ü, kantaksantinin \% 66.29’u, apoesterin \% 9.81'i yumurtada depolanmıştır.

Çizelge 7. Yemlerin bireysel karoten miktarlarının ortalamaları ve standart hataları $(\mu \mathrm{g} / \mathrm{g})$

\begin{tabular}{clcccccc}
\hline Dönem Irklar & $\begin{array}{c}\text { Tanımlanamaya } \\
\text { n karoten }\end{array}$ & Lutein & Zeaksantin Kantaksanti & Apoester & $\beta$ Karoten \\
\hline 1 & Tinted44 & $0.31 \pm 0.07$ & $3.82 \pm 0.29^{\mathrm{b}}$ & $5.88 \pm 0.30^{\mathrm{a}}$ & $0.84 \pm 0.06^{\mathrm{b}}$ & $1.07 \pm 0.10^{\mathrm{b}}$ & $0.35 \pm 0.03$ \\
1 & Novagen32 & $0.21 \pm 0.01$ & $6.14 \pm 0.23^{\mathrm{a}}$ & $1.61 \pm 0.12^{\mathrm{c}}$ & $0.81 \pm 0.08^{\mathrm{b}}$ & $0.72 \pm 0.15^{\mathrm{b}}$ & $0.37 \pm 0.05$ \\
1 & Lohman45-58 & $0.39 \pm 0.02$ & $6.38 \pm 0.20^{\mathrm{a}}$ & $5.24 \pm 0.17^{\mathrm{b}}$ & $1.26 \pm 0.03^{\mathrm{a}}$ & $1.58 \pm 0.18^{\mathrm{a}}$ & $0.37 \pm 0.03$ \\
& & & & & & \\
2 & Tinted49 & $0.34 \pm 0.06$ & $4.23 \pm 0.72^{\mathrm{ab}}$ & $6.54 \pm 1.11^{\mathrm{a}}$ & $0.94 \pm 016$ & $1.19 \pm 0.20$ & $0.39 \pm 0.07$ \\
2 & Novagen37 & $0.36 \pm 0.01$ & $6.36 \pm 1.64^{\mathrm{a}}$ & $1.67 \pm 0.42^{\mathrm{c}}$ & $0.84 \pm 0.22$ & $0.75 \pm 0.20$ & $0.38 \pm 0.10$ \\
2 & Lohman50 & $0.30 \pm 0.01$ & $3.70 \pm 0.16^{\mathrm{ab}}$ & $5.72 \pm 0.25^{\mathrm{ab}}$ & $0.82 \pm 0.04$ & $1.04 \pm 0.05$ & $0.34 \pm 0.01$ \\
2 & Lohman 63 & $0.44 \pm 0.01$ & $2.74 \pm 0.17^{\mathrm{b}}$ & $4.24 \pm 0.27^{\mathrm{b}}$ & $0.61 \pm 0.04$ & $0.77 \pm 0.05$ & $0.26 \pm 0.02$ \\
& & & & & & \\
3 & Tinted53 & $0.35 \pm 0.07$ & $4.41 \pm 0.83^{\mathrm{ab}}$ & $6.82 \pm 1.28^{\mathrm{a}}$ & $0.98 \pm 0.18^{\mathrm{a}}$ & $1.24 \pm 0.23^{\mathrm{a}}$ & $0.41 \pm 0.08^{\mathrm{a}}$ \\
3 & Novagen41 & $0.21 \pm 0.03$ & $5.54 \pm 0.36^{\mathrm{a}}$ & $1.45 \pm 0.09^{\mathrm{c}}$ & $0.74 \pm 0.05^{\mathrm{ab}}$ & $0.65 \pm 0.04^{\mathrm{c}}$ & $0.33 \pm 0.02^{\mathrm{ab}}$ \\
3 & Lohman54 & $0.30 \pm 0.01$ & $3.70 \pm 0.16^{\mathrm{bc}}$ & $5.72 \pm 0.25^{\mathrm{ab}}$ & $0.82 \pm 0.04^{\mathrm{ab}}$ & $1.04 \pm 0.05^{\mathrm{ab}}$ & $0.34 \pm 0.01^{\mathrm{ab}}$ \\
3 & Lohman67 & $0.22 \pm 0.02$ & $2.24 \pm 0.27^{\mathrm{c}}$ & $4.24 \pm 0.27^{\mathrm{b}}$ & $0.61 \pm 0.04^{\mathrm{b}}$ & $0.77 \pm 0.05^{\mathrm{bc}}$ & $0.26 \pm 0.02^{\mathrm{b}}$ \\
\hline
\end{tabular}

${ }^{\text {abc }}$ Aynı sütundaki ve dönemdeki farklı harfler istatistik olarak önemlidir $(\mathrm{p}<0.05)$.

\subsection{Yemlerin Vitamin A ve Vitamin $E$ içerikleri}

Muş ve Van illerinde yetiştiriciliği yapılan yumurta tavuklarının beslenmesinde kullanılan yemlerin vitamin A (retinol) ve vitamin E içerikleri hayvan ırk ve yaşlarına göre Çizelge 8'de verilmiştir. Vitamin A içerikleri bakımından bir farklılık saptanmaz iken, yemlerin vitamin E içerikleri her 3 
dönemde de Novagen 1rkı hayvanların yemlerinde önemli düzeyde düşük olduğu görülmektedir $(\mathrm{P}<0.05)$. Yemlerin vitamin A içerikleri; Karageçili ve Karadaş (2015) tarafından yapılan çalışmada ticari yumurta tavuk yemlerinin Vitamin A içerikleri 1-5 $\mu \mathrm{g} / \mathrm{g}$ olarak saptanmış olup bu çalışmada ise 0 - $4 \mu \mathrm{g} / \mathrm{g}$ değeri arasında tespit edilmiş olup paralellik göstermektedir.

$\mathrm{Bu}$ çalışmada yemlerin vitamin E içerikleri 46-115 $\mu \mathrm{g} / \mathrm{g}$ arasında tespit edilmiş olup, benzer bir çalışma olan Karageçili ve Karadaş (2015) tarafinda 53. Hafta Lohman yumurtacıların yemleri 140.68 $\mu \mathrm{g} / \mathrm{g}$ vitamin E içeriği, 54. Hafta Lohman yumurtacı tavuk yemlerinin vitamin E içeriği $100.46 \mu \mathrm{g} / \mathrm{g}$ düşük olduğu, ancak diğer haftalarda 33-43. Hafta sonuçları olan 85.01-87.66 $\mu \mathrm{g} / \mathrm{g}$ sonuçları ile bu çalışmada, 45-50. Hafta vitamin E içerikleri 115.91-100.91 $\mu \mathrm{g} / \mathrm{g}$ sonuçlarının daha yakınlık gösterdiği saptanmıştır.

Vitamin E konsantrasyonlarının yumurtaya aynı şekilde yansıdığı ve yemdeki miktarları yüksek olan grupların yumurtalarında da daha yüksek vitamin A ve Vitamin E biriktiği görülmektedir.

Çizelge 8. Yemlerin Vitamin A (retinol) ve Vitamin E miktar $(\mu \mathrm{g} / \mathrm{g})$ ortalamaları ve standart hataları

\begin{tabular}{cccc}
\hline Dönem & Yem & Vitamin A (Retinol) & Vitamin E \\
\hline 1 & Tinted 44 & $4.01 \pm 2.50$ & $106.17 \pm 9.01^{\mathrm{a}}$ \\
1 & Novagen 32 & $0.01 \pm 0.006$ & $46.26 \pm 0.75^{\mathrm{b}}$ \\
1 & Lohman 45-58 & $0.37 \pm 0.33$ & $115.91 \pm 4.36^{\mathrm{a}}$ \\
\hline 2 & Tinted 49 & $1.33 \pm 0.93$ & $82.02 \pm 7.05^{\mathrm{b}}$ \\
2 & Novagen 37 & $0.09 \pm 0.07$ & $58.39 \pm 2.71^{\mathrm{c}}$ \\
2 & Lohman 50 & $2.00 \pm 1.95$ & $100.46 \pm 6.51^{\mathrm{a}}$ \\
2 & Lohman 63 & $3.54 \pm 2.75$ & $91.91 \pm 5.20^{\mathrm{ab}}$ \\
\hline 3 & Tinted 53 & - & $88.14 \pm 3.00^{\mathrm{ab}}$ \\
3 & Novagen 41 & $0.09 \pm 0.031$ & $77.05 \pm 1.36^{\mathrm{b}}$ \\
3 & Lohman 54 & $2.00 \pm 1.95$ & $100.46 \pm 6.51^{\mathrm{a}}$ \\
3 & Lohman 67 & $3.54 \pm 2.75$ & $91.91 \pm 5.20^{\mathrm{a}}$ \\
\hline
\end{tabular}

${ }^{\text {abc }}$ Aynı sütundaki farklı harfler istatistik olarak önemlidir $(\mathrm{p}<0.05)$.

\section{Sonuç}

Bu çalışmada Türkiye'de Van ve Muş illerinde ticari yumurta tavukçuluğu yapan işletmelerde alınan yem ve yumurta örneklerinin Roche skala renk skoru, Minolta $L^{*}, a^{*}, b^{*}$ değerleri ile vitamin A, E ve karoten içerikleri bakımından hayvan ırkları ve yaşlarına göre değişim durumları saptanmıştır. Çalışma sonunda;

1. Roche skala değerleri (RCF) 10.45-12.50 aralığında saptanmış olup araştırmaya konu olan ticari firma yumurtalarının Avrupa ve Asya kıtasında tüketicilerin tercih ettikleri yumurta sarısı RCF 10-14 skala değerleri arasında kaldığı, Minolta Sarılık b* değeri 33-45 ve kırmızılık a* değeri 5-7 sonuçlarının tüketicilerin için arzu edilen sarılık ve kırmızılıkta olduğu saptanmıştır.

2. Çalışma sonunda yumurta sarılarının toplam karoten, retinol ve vitamin $\mathrm{E}$ içeriği; en düşük Tinted ırkı 33 haftalık yaşta saptanmış ancak bu farklılığın yemden kaynaklandığı çünkü bu tavukların yemlerinin de incelenen parametrelerce düşük olduğu tespit edilmiştir.

3. Çalışmadan elde edilen bireysel karoten içerikleri ile ilgili bulgular Türkiye'de ticari yumurtalarda önemli düzeyde insan sağlığı için faydalı olabilecek düzeyde lutein + zeaksantin içerdiği, bu içeriğin Türkiye'de kullanılan yumurta tavuk yemlerinin Misır Soya temelli olmasından kaynaklandığ 1 ancak sentetik formda kantaksantin ve çok az miktarda da olsa apoester karotenlerin de yemlerde kullanıldığı tespit edilmiştir.

4. Kantaksantin retinada renk kristalleşmeleri oluşturduğu ve görme kaybına neden olabileceği kaygısı nedeniyle Avrupa Birliği tarafından 2002 y1lında; yumurta tavuğu rasyonlarında maksimum kullanılacak kantaksantin miktarı $8 \mathrm{mg} / \mathrm{kg}$ olarak sınırlandırmıştır. Bu çalışmada elde edilen bulgular yemlerde kullanılan kantaksantin miktarının $8 \mathrm{mg} / \mathrm{kg}$ 'ın çok altında $1-2$ $\mathrm{mg} / \mathrm{kg}$ civarında kullanıldığı ancak risk varlığ1 nedeni ile hiç kullanılmaması yönünde kantaksantin yerine ülkemizde üretimi yaygın olan kırmızı biber ve domates yan ürün ve ekstraklarının alternatif doğal renk maddeleri olarak kullanılabilmesi hususunda yasal düzenlemelerin yapılması gereği vardır. 


\section{Teşekkür}

Bu çalışma Van Yüzüncü Yıl Üniversitesi Bilimsel Araştırma Projeleri birimi tarafından FYL2018-7233 No'lu proje kapsamında desteklenmiştir.

Makalenin yayına hazırlanması sırasında emekleri olan ilgili tüm editör ve hakemlere, istatistik düzeltmeleri yapan sayın Prpf. Dr. Sıdık Keskin'e, laboratuvar çalışmaları sırasında yardımlarını esirgemeyen Araş. Gör. Sezen Tayam ve Dr. Araş. Gör. Mehmet Reşit Karageçili'ye sonsuz teşekkürlerimizi sunarı.

Kaynakça

Alay, T., \& Karadas, F. (2016). The effects of carotenoids in quail breeder diets on egg yolk pigmentation and breeder performance. Acta Agriculturae Scandinavica, Section 66, 206-214.

Ciapara, IH., Valenzuela, LF., Goycoolea, FM., \& Monal, WA. (2004). Microencapsulation of astaxanthin in a chitosan matrix, Carbohydrate Polymers. Elsevier 56(1), 41-45.

Dufossé, L., Galaup, P., Yaron. A., Arad, SM., Blanc, P., Murthy, KNC., \& Ravishankar, G. (2005). Microorganisms and microalgae as sources of pigments for food use: A scientific oddityor an industrial reality? Trends in Food Science and Technology 16, 389-406.

EFSA (2014). Scientific opinion on the safety and efficacy of canthaxanthin as a feed additive for poultry and for ornamental birds and ornamental fish. EFSA Journal 12(1), 3527.

Faitarone, A. B. G., Garcia, E. A., Roca, R. O., Andrade, E. N., Vercese, F., \& Pelícia, K. (2016). Yolk color and lipid oxidation of the eggs of commercial white layers fed diets supplemented with vegetable oils. Brazilian Journal of Poultry Science 18, 09-16.

Galobart, J., Sala, R., Rincón-Carruyo, X., Manzanilla, E.G., Vil, B., \& Gasa, J. (2004). Egg yolk color as affected by saponified oleoresin of red pepper (Capsicum annuum) fed to laying hens. Poultry Science 69, 462-470.

Günal, M., \& Bakirci, A.S. (2006). Kurutulmuş domates ve elma posalarının pnaç bıldırcın rasyonlarında kullanım olanakları. Süleyman Demirel Üniversitesi, Ziraat Fakültesi Dergisi $1(2), 28-37$.

Gürbüz, Y., Kamalak, A., Çiçek, T., \& Sakarya, M. (2004). Doğal karotenoid Kaynakları ve yumurta Sarı Rengi. 4. Ulusal Zootekni Bilim Kongresi, 1-3 Eylül, Isparta, 325-330.

Jeroch, H., Drochner, W., \& Simon, O. (1999). Ernährung landwirtschaftlicher Nutztiere. Verlag Eugen Ulmer Stuttgart 525.

Jeroch, H., Flachowsky, G., \& Weißbach, F. (1993). Futtermittelkunde. Gustav Fischer Verlag Jena. Stuttgart 422.

Karadas, F., Grammenidis, E., Surai, P.F., Acamovic, T., \& Sparks, NHC. (2006). Effects of carotenoids from lucerne, marigold and tomato on egg yolk pigmentation and carotenoid composition. British Poultry Science 47, 561-566.

Karageçili, M.R., \& Karadaş, F. (2015). Yumurtacı tavuklarda yumurta sarısında biriken yağda çözünen antioksidanlar (karotenoid, vitamin e ve vitamin a) üzerine yaşın etkisi. YYÜ Tarım Bilimleri Dergisi 26(1), 26-32.

Kaya, H., \& Macit, M. (2019). Yumurtlamanın son dönemindeki yumurtacı tavukların rasyonlarına bor (Ortoborik asit) ilavesinin performans ve bazı serum parametreleri üzerine etkileri. Yüzüncü Yıl Üniversitesi Tarım Bilimleri Dergisi 29(1): 106-113.

Kırkpınar, F., \& Erkek, R. (1999). Sarı mısır temeline dayalı karma yemlere ilave edilen bazı doğal ve sentetik renk maddelerinin yumurta sarısının rengi ve verim üzerine etkileri. $\operatorname{Tr} J$ of Veterinary and Animal Sciences 23, 15-21.

Knoblich, M., \& Latsaw, J. D. (2000). Tomato byproducts as a feed ingredient and source of carotenoids for laying. Hends. Poultry Science 79(1), 16.

Kushwaha, K., Saini, A., Saraswat, P., Agarwal, M., \& Saxena J. (2014). Colorful World of Microbes carotenoids and their applications. Advances in Biology 13.

Latscha, T. (1990). Carotenoids in animal nutrition. Kanatl Hayvan Bilimi 71(4), 711-717.

Leeson, S., \& Summers, JD. (1997). Commercial Poultry Nutrition, 2nd edn, University Books, Guelph, Canada 355.

Lokaewmanee, K., Yamauchi, K., Komori., T., \& Saito, K. (2010). Effects on egg yolk colour of paprika or paprika combined with marigold flower extract. Italian Journal of Animal Science 9, 356-359. 
Macit, M., Çelebi, Ş., Kaya, H., Esenbuğa, N., \& Karaoğlu, M. (2007). Değişik Oranlarda Humat İçeren Rasyonların ve Canlı Ağırlı̆ın Yumurtacı Tavuklarda Performans ve Yumurta Kalite Özellikleri Üzerine Etkileri. IV. Ulusal Hayvan Besleme Kongresi 24-28 Haziran, Bursa 252256.

Mattea, F., Martín, Á., \& Cocero, MJ. (2009). Carotenoid processing with supercritical fluids. Journal of Food Engineering 93(3), 255-265.

Mortensen, A. (2006). Carotenoids and other pigments as natural colorants. Chr. Hansen A/S, Color Research, Development and Application Bøge Allé 10-12, DK-2970 Hørsholm, Denmark

NRC (1994). National Research Council. Nutrient Requirements of Poultry. 9th Revised Edition. National Academy Press Washington D.C.

Nys, Y. (2000). Dietary carotenoids and egg yolk coloration-a review. Archive Geflugelk 64, 45-54.

Okur, A., Şamlı, HE. (2014). Yumurtanın besin değeri ve kalite kriterleri. Yumurta Haber Bülteni 20, 16-17.

SAS (2014). SAS/STAT. Statistical analysis system for Windows. Relase 9.4. SAS Institute Inc

Skřivan, M., Englmaierová, M., Skřivanová, E., \& Bubancová, I. (2015). Increase in lutein and zeaxanthin content in the eggs of hens fed marigold flower extract. Czech Journal of Animal Science 60(3), 89-96.

Surai P. F., Speake B. K \& Sparks N. H. C. (2001). Carotenoids in avian nutrition and embryonic development. Absorption, availability and levels in plasma and egg yolk. Journal of Poultry Science 38, 1-27.

Surai, P. F. (2000). Effect of selenium and vitamin E content of the maternal diet on the antioxidant system of the yolk and the developing chick. British Poultry Science 41(2), 235-243.

Surai, P. F., \& Sparks, N. H. C. (2001). Designer eggs: from improvement of egg composition to functional food. Trends in food science \& Technology 12(1), 7-16.

Surai, P. F., Noble, R. C., \& Speake, B. K. (1996). Tissue-specific differences in antioxidant distribution and susceptibility to lipid peroxidation during development of the chick embryo. Biochimica et Biophysica Acta (BBA)-Lipids and Lipid Metabolism 1304(1), 1-10.

Surai, P. F., Speake, B. K., \& Sparks, N. H. C. (2001). Carotenoids in avian nutrition and embryonic development. 1. absorption, availability and levels in plasma and egg yolk. The Journal of Poultry Science 38(1), 1-27.

Surai, P.F. (2002). Natural Antioxidants in Avian Nutrition and reproduction. Nottingham University Press Manor Farm, Main Street, Thrumpton Nottingham, NG11 0AX, United Kingdom.

Şamlı HE, Şenköylü N, Akyürek H, \& Ağma A. (2005). Doğal pigmentlerin yaşlı tavuklarda yumurta sarisina etkileri. Journal of Tekirdag Agricultural Faculty 2(3), 281-286.

Vershinin, A. (1999). "Biological functions of carotenoids-diversity and evolution," BioFactors 10, 99104.

Yenice, E., Mızrak, C., Can, M., \& Yıldırım, U. (2007). Yumurta tavuğu yemlerinde doğal renk maddesi kem glo' nun sentetik renk maddeleri yerine kullanım olanakları. Tavukçuluk Araştırma Dergisi $11,16-17$ 